\title{
Amount of folic acid in different types of nutrition used in the neonatal period
}

\author{
Revakova $\mathrm{T}^{1}$, Revak $\mathrm{O}^{2}$, Vasilenkova $\mathrm{A}^{3}$, Behulova $\mathrm{D}^{3}$, Brucknerova $\mathrm{I}^{4}$ \\ 1st Department of Paediatrics, Medical Faculty, Comenius University in Bratislava and University \\ Children's Hospital, Bratislava, Slovakia. zikavska@gmail.com
}

\begin{abstract}
BACKGROUND: Folic acid is one of the important supplements for adequate development during pregnancy. A higher intake of folic acid during pregnancy and lactation is recommended.

METHODS: In prospective study the group of premature newborns $(n=52)$ and the type of nutrition were observed. The red blood cell (RBC) folate concentration levels were determined in the first 24 hours after delivery, before and after oral treatment with folic acid (100 $\mu \mathrm{g} /$ day $)$. Immunochemical analysis for the determination of folate in erythrocytes was performed.

RESULTS: In the group of premature newborns the RBC folate concentration levels after treatment were significantly increased $(p<0.0001)$. A dynamic increase in the concentration levels of folates in erythrocytes before and after treatment was observed, in spite of the reciprocally decreasing blood count parameters, but without any statistically significant correlation. The infant nutrition before treatment contained significantly higher amount of folic acid in fortified breast milk compared to breast milk ( $p=0.04)$.

CONCLUSION: The various types of nutrition for preterm newborns contain a different amount of folic acid. It poses a question of real needs of these patients. The best way to determine the optimal whole amount of folate is to know the real levels of folate in premature newborns (Tab. 2, Fig. 5, Ref. 26). Text in PDF www.elis.sk. KEY WORDS: folic acid, breast milk, milk fortifier, preterm formula milks, neonatal nutrition.
\end{abstract}

Abbreviations: NTD - neural tube defects, RBC - red blood cell.

\section{Introduction}

Folic acid is one of the important supplements for adequate development of foetus during pregnancy as well as after birth. Folic acid is a vitamin with importance in pregnancy due to its role in the development of the brain and nervous system and the prevention of foetal neural tube defects (NTD) (1). In some developing countries there are programs of multiple micronutrient or food supplementation. It confirms the effects of multiple micronutrient supplementation to undernourished pregnant women on their offsprings' development (2). Malnutrition and neonatal

\footnotetext{
${ }^{1} 1$ st Department of Paediatrics, Medical Faculty, Comenius University in Bratislava and University Children's Hospital, Bratislava, Slovakia, ${ }^{2}$ Department of Food Hygiene and Safety, Faculty of Biotechnology and Food Science, Slovak University of Agriculture, Slovakia, ${ }^{3}$ Department of Clinical Biochemistry, University Children's Hospital, Bratislava, Slovakia, and ${ }^{4}$ Department of Neonatology and Intensive Medicine, Medical School, Comenius University, Bratislava, Slovakia

Address for correspondence: T. Revakova, MD, 1st Department of Paediatrics, Medical Faculty, Comenius University in Bratislava and University Children's Hospital, Limbova 1, SK-833 40 Bratislava, Slovakia. Phone: +421.911148447

Acknowledgement: This work was supported by grants (GUK 320/2011, 376/2012). The laboratory work was performed in cooperation with the Department of Clinical Biochemistry in Children's University Hospital, Slovak Republic.
}

deaths increase the the importance of intrauterine health for future cognitive development in these countries (3). The folic acid and iron supplementation of pregnant woman could be beneficial to prevent children's malnutrition (4). Studies show that the use of micronutrient fortified supplementary foods and beverages (iron, zinc, copper, iodine, selenium, vitamins A, D, E, C, B1, B2, B6, $\mathrm{B} 12$, folic acid, niacin and pantothenic acid), increase mean birthweight (5). On the other hand some developed countries approved mandatory folic acid fortification programs to decrease prevalence of neural tube defects. Mandatory fortification of flour and certain other grain products in many countries has been associated with a reduction in NTD incidence. However, other deficiencies or suboptimal status of B vitamins have been repeatedly reported in pregnant women also in high-income countries (1). In Slovak Republic a higher intake is recommended during pregnancy and lactation. Minimal recommended amount of folic acid during pregnancy is $400 \mu \mathrm{g}$ and during lactation $300 \mu \mathrm{g}$. The needs of folic acid in each period of life vary. For adolescents the intake of $200 \mu \mathrm{g}$ of folic acid is recommended and under six months of age the recommended dose is $60 \mu \mathrm{g}$ daily $(6,7)$. But in this sensitive part of life there is a need for adequate nutrition. The outcome of this supplementation for preterm newborns can be measured. An overdose in the growing bodies of preterm newborns could disrupt metabolic balance with potential risks (8). In 2005 a study was published in Ireland reporting some cases of newborns with high level of unmetabolised folic acid in spite of voluntary folic acid fortification's program (9). Some studies are interested in the pos- 
Tab. 1. Various amounts of folic acid (FA) fortification in some products of infant formula milks, breast milk and breast milk fortifiers in Slovakia.

\begin{tabular}{lcllc}
\hline product & amount of FA* & & product & amount of FA* \\
\cline { 1 - 1 } BEBA 1 Pro & $9.5 \mu \mathrm{g}$ & & Nutrilon 1 & $12 \mu \mathrm{g}$ \\
BEBA 1 HA & $12 \mu \mathrm{g}$ & & Nutrilon 1 HA & $9 \mu \mathrm{g}$ \\
BEBA Sensitive & $12 \mu \mathrm{g}$ & & Nutrilon 1 AR & $9.3 \mu \mathrm{g}$ \\
Beba AR & $12 \mu \mathrm{g}$ & & Nutrilon 1 AC & $8.9 \mu \mathrm{g}$ \\
PreBEBA Preemie & $41 \mu \mathrm{g}$ & & Nutrilon Low Lactose & $8.9 \mu \mathrm{g}$ \\
PreBEBA Discharge & $13 \mu \mathrm{g}$ & & Nenatal 0 & $28 \mu \mathrm{g}$ \\
Alfaré & $6.3 \mu \mathrm{g}$ & & Nenatal 1 & $20 \mu \mathrm{g}$ \\
Althéra & $7.4 \mu \mathrm{g}$ & & Nutrilon 1 Extra & $12 \mu \mathrm{g}$ \\
Sunar 1 extra & $10 \mu \mathrm{g}$ & & Nutrilon 1 ADC & $10 \mu \mathrm{g}$ \\
Breast milk $* * *$ & $9 \mu \mathrm{g}$ & & Nutrilon 1 Soya & $9 \mu \mathrm{g}$ \\
FM 85 $* *$ & $40 \mu \mathrm{g}$ & & BMF ** & $49 \mu \mathrm{g}$ \\
\hline
\end{tabular}

* the amount of FA is calculated based on $100 \mathrm{ml}$ of milk; ** breast milk fortifiers; *** Mackey and Picciano, 1999

\begin{tabular}{lc}
\hline product & amount of FA* \\
\hline Hami 1 & $13 \mu \mathrm{g}$ \\
France Lait 1 & $6.7 \mu \mathrm{g}$ \\
France Lait LF & $13.5 \mu \mathrm{g}$ \\
Milupa Basic P & $7 \mu \mathrm{g}$ \\
France Lait AR & $13.5 \mu \mathrm{g}$ \\
Nestlé Sinlac & $11 \mu \mathrm{g}$ \\
ALL 110 & $11 \mu \mathrm{g}$ \\
Neocate & $5.7 \mu \mathrm{g}$ \\
Monogen & $8.22 \mu \mathrm{g}$ \\
Infanrini & $15 \mu \mathrm{g}$ \\
IMTV-AM 1 & $20 \mu \mathrm{g}$ \\
\hline
\end{tabular}

sible adverse effects of this unmetabolised folic acid in the body, because the safe upper limits in newborns are not known. Benefits of folic acid are clearly known worldwide. Over the past several decades a decrease in the incidence of NTD and other congenital anomalies after folic acid fortification has been published (10, 11). Effective intervention programs are needed with the aim to improve periconceptional intake of folic acid. The prevention of NTD is much better than medical care (12). A healthy balanced diet provides the best basis for optimal pregnancy outcome, lactation performance and complementary feeding. However, supplements or fortified foods may be needed to cover the high requirements especially of critical vitamins such as vitamin D and folic acid and to correct unfavorable dietary patterns in women or to adapt foods to needs of young children (1). Preterm formula milks and breast milk fortifiers provide sufficient folic acid to prevent folate deficiency in preterm infants (13). The variability of different amounts of folic acid in some products of infant formula milks in Slovakia is documented in Table 1.

\section{Materials and methods}

In this prospective study we observed the group of premature newborns $(\mathrm{n}=52$; gestational age from 27 th to 36 th gestational week; median of birth weight $1780 \pm 450$ grams) who were hospitalized at the Department of Neonatology at University Children's Hospital in Bratislava. The red blood cell folate concentration levels were determined from venous blood samples in the first 24 hours after delivery ("A" samples), before ("B" samples) and after ("C" samples) treatment with folic acid (100 $\mu \mathrm{g} /$ day) orally. The nutrition type (breast milk, preterm formula milk-containing $28 \mu \mathrm{g}$, breast milk with added fortifier-containing $49 \mu \mathrm{g}$ ) before and after treatment was documented. Venesection was not done solely for the purposes of this study. All newborns with the hemolytic disease of the newborn, multiple congenital anomalies and severe bleeding (blood losses more than $2 \mathrm{~g} / \mathrm{dl} / 24$ hours) were excluded from the study. Blood samples for determining RBC folate were collected in vacutainers containing EDTA and taken to the Department of Clinical Biochemistry in Hospital for Children in Bratislava. Within 2 hours of collection full blood count analysis (especially haemoglobin, haematocrit, erythrocytes) was done. Remaining blood was stored at $-20{ }^{\circ} \mathrm{C}$ for up to one month. The samples were defrosted and processed within one month accord- ing to specifications of the producer sets and consistent with the literature data (14). After this period the lysing agent ( $1.5 \mathrm{ml} 0.2 \%$ ascorbic acid) was added to $50 \mu 1$ of whole blood for the red blood cell (RBC) folate analysis (Roche Diagnostics, Germany). Immunochemical analysis was performed with the use of chemiluminescent emission (analyser cobas e 411). It was based on a competitive test using natural folate binding protein specific for folate. Folate competes with the added folate for the binding sites of folate binding protein labelled with ruthenium complex.

Statistical analyses were based on frequency analysis calculated at $97 \%$ accuracy with confidence limits for proportion. Analysis of median values for RBC folate concentration levels and blood count analysis (haemoglobin, haematocrit, erythrocytes) were executed using the Mann-Whitney or Kruskal-Wallis tests. The relationship between RBC folate concentration levels and nutrition type and blood count parameters were assessed by Kendall rank correlation coefficient. Differences were regarded as statistically significant at $\mathrm{p}<0.05$. Analyses were performed by statsdirect version 2.8.0.

The study was approved by the Ethics Committee of University Hospital in Bratislava and the Ethics Committee of Children's University Hospital in Bratislava. Informed consent was obtained from every enrolled newborn's mother.

\section{Results}

In the group of premature newborns ( $\mathrm{n}=52$; gestational age from 27 th to 36 th gestational week) the RBC folate concentration levels were determined in the first 24 hours after delivery (" $A$ " samples). In "A" samples the median was $1188 \mathrm{ng} / \mathrm{ml}$ (967 ng/ $\mathrm{ml}-1423 \mathrm{ng} / \mathrm{ml}$; 25th and 75th percentile). After full oral intake of breast milk or preterm formula milk $(160 \mathrm{ml} / \mathrm{kg} / \mathrm{day})$ taken orally daily, the oral treatment with $100 \mu \mathrm{g}$ /day of folic acid was started. The median age of full oral intake was on the 11th day of life. Before the first dose of folic acid the blood count parameters (haemoglobin, haematocrit, erythrocytes) and then the RBC folate concentration levels were determined ("B" samples). In "B" samples the median of RBC folate concentration levels was 1103 $\mathrm{ng} / \mathrm{ml}(800 \mathrm{ng} / \mathrm{ml}-1408 \mathrm{ng} / \mathrm{ml} ; 25$ th and 75 th percentile). There were no significant changes in the $\mathrm{RBC}$ folate concentration levels between "A" and "B" samples. In "C" samples the median of RBC folate concentration levels was $1313 \mathrm{ng} / \mathrm{ml}(1078 \mathrm{ng} / \mathrm{ml}-1701$ $\mathrm{ng} / \mathrm{ml} ; 25$ th and 75 th percentile). After three weeks of treatment 
Tab. 2. Changes in red blood cell folate concentration levels after birth, before and after three weeks of daily oral treatment with folic acid $(100 \mu \mathrm{g} / \mathrm{day})$ in preterm newborns $(\mathrm{n}=\mathbf{5 2})$.

\begin{tabular}{lccc}
\hline RBC folate concentration (ng/ml) & \multicolumn{3}{c}{ percentile } \\
\cline { 2 - 4 } & 25. & 50. & 75. \\
\hline "A" samples - first 24 hours after delivery & 967 & 1188 & 1423 \\
"B" samples - before treatment with folic acid & 800 & 1103 & 1408 \\
"C" samples - after treatment with folic acid & 1078 & 1313 & 1701 \\
\hline
\end{tabular}

with folic acid ( $100 \mu \mathrm{g} / \mathrm{day})$, the RBC folate concentration levels were significantly increased $(\mathrm{p}<0.0001)$. The results of our findings are documented in Table 2.

A dynamic increase in the concentration levels of folates in erythrocytes before and after treatment was observed, in spite of the reciprocally decreasing blood count parameters (haemoglobin, haematocrit, erythrocytes), but without any statistically significant correlation. The statistically significant decrease of haemoglobin $(\mathrm{p}=$ 0.002 ) in spite of folic acid treatment is documented in Figure 1. Similar important changes were found in haematocrit $(p=0.0001)$ and erythrocytes $(p=0.003)$, which are documented in Figures 2 and 3 .

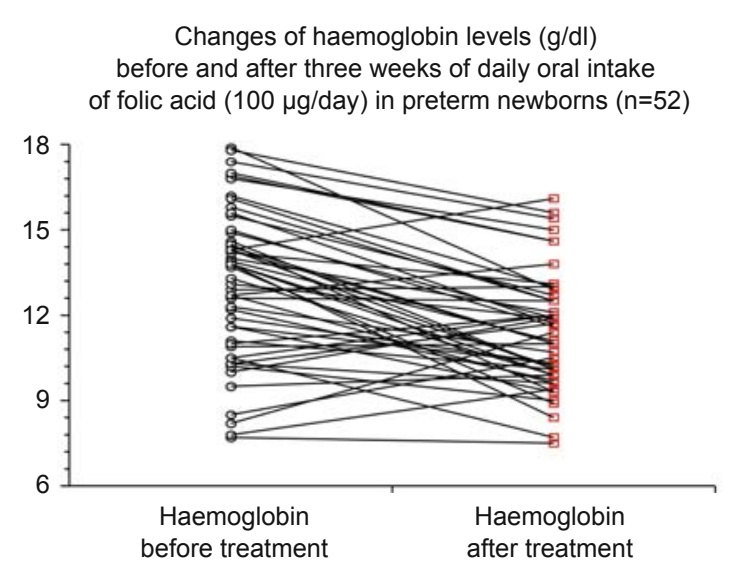

Fig. 1. Changes in haemoglobin levels before and after three weeks of daily oral intake of folic acid $(100 \mu \mathrm{g} / \mathrm{day})$ in preterm newborns $(\mathbf{p}=\mathbf{0 . 0 0 2})$

Changes in haematocrit (\%) levels before and after three weeks of daily oral intake of folic acid (100 $\mu \mathrm{g} /$ day $)$ in preterm newborns $(n=52)$

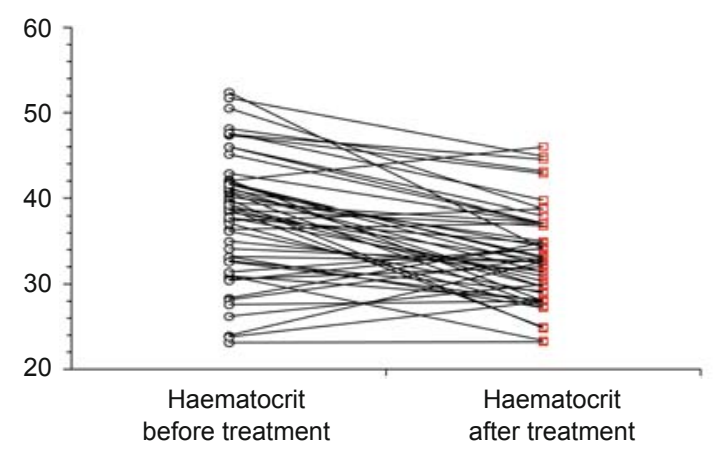

Fig. 2. Changes in haematocrit (\%) levels before and after three weeks of daily oral intake of folic acid $(100 \mu \mathrm{g} / \mathrm{day})$ in preterm newborns $(p=0.0001)$
The next aim of this study was to show an impact of nutrition type on RBC folate concentration levels in addition to the treatment with folic acid $(100 \mu \mathrm{g} /$ daily). In this group of preterm newborns we used three different types of nutrition. Preference was assigned to breast milk $(\mathrm{n}=34)$ or, depending on the clinical status, breast milk with added fortifier $(n=7)$ (containing $49 \mu \mathrm{g}$ of folic acid in $100 \mathrm{ml}$ ). Preterm formula milks (containing $28 \mu \mathrm{g}$ of folic acid in $100 \mathrm{ml}$ ) were used when breastfeeding was impossible. These types of nutrition are illustrated in Figure 4.

The RBC folate concentration levels were measured before and after the treatment with folic acid. When comparing different nutrition types we found significantly higher RBC folate concentration levels in preterm newborns who were fed by breast milk with added fortifier $(\mathrm{p}=0.04$; median $1469 \mathrm{ng} / \mathrm{ml})$, compared to breast milk (median $1038 \mathrm{ng} / \mathrm{ml}$ ) before treatment. Similar result on the border of statistical significance was found in the case of preterm formula milk ( $\mathrm{p}=0.072$; median $1357 \mathrm{ng} / \mathrm{ml})$ compared to breast milk. After treatment the results for the two types of nutrition were similar. On the border of statistical significance were the higher RBC folate concentration levels in preterm newborns who were fed by preterm formula milk ( $\mathrm{p}=0.071$; median $1694 \mathrm{ng} /$ $\mathrm{ml}$ ) compared to breast milk (median $1323 \mathrm{ng} / \mathrm{ml}$ ). These changes are documented in Figure 5.

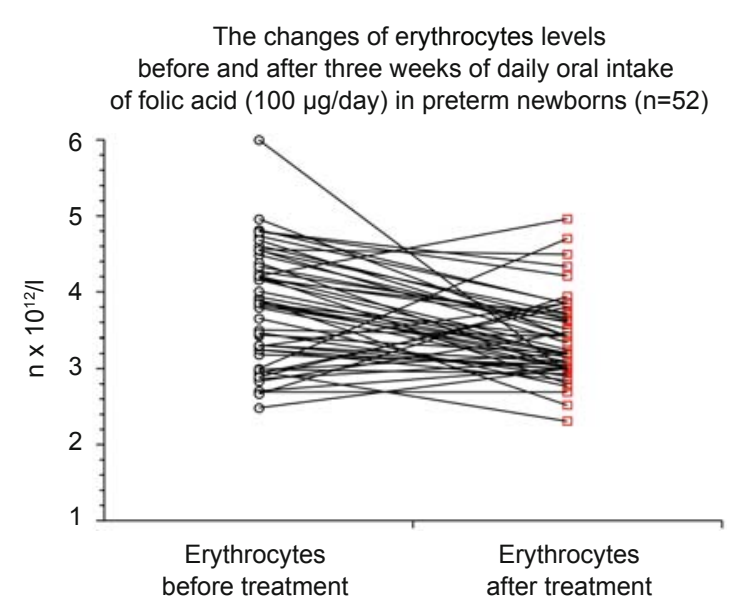

Fig. 3. Changes in erythrocytes levels before and after three weeks of daily oral intake of folic acid $(100 \mu \mathrm{g} / \mathrm{day})$ in preterm newborns $(\mathrm{p}=\mathbf{0 . 0 0 3})$

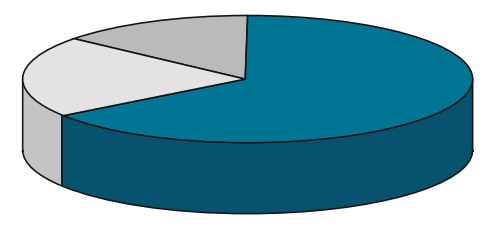

Breast milk $(n=34)$

Preterm formula milk $(\mathrm{n}=11)$

Breast milk with added fortifier $(n=7)$

Fig. 4. Types of infant nutrition (breast milk, preterm formula milk, breast milk with added fortifier) during treatment with folic acid in preterm newborns 


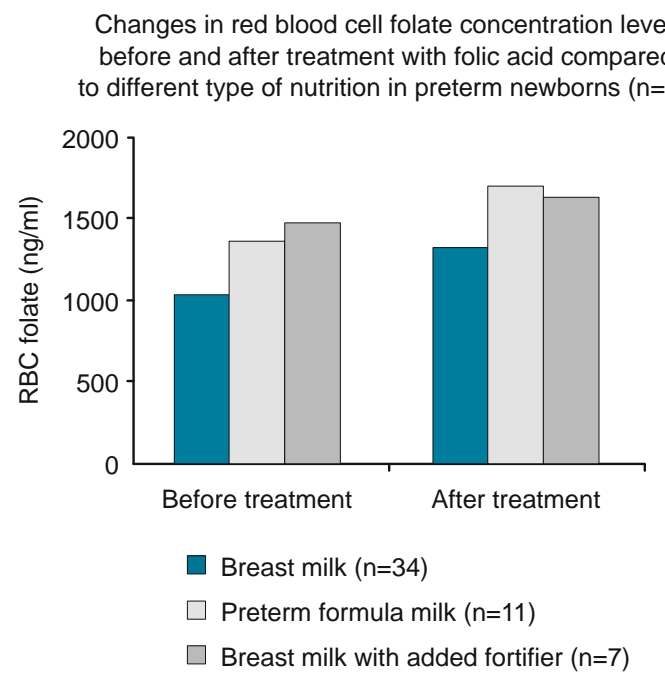

Fig. 5. Changes in red blood cell folate concentration levels before and after treatment with folic acid $(100 \mu \mathrm{g} / \mathrm{day})$ compared to different types of nutrition in preterm newborns. Comparison with breast milk with added fortifier (containing $49 \mu \mathrm{g}$ of folic acid in $100 \mathrm{ml}$ ) (containing $28 \mu \mathrm{g}$ of folic acid in $100 \mathrm{ml})$ and breast milk $(p=0.04$; containing 40 $\mu \mathrm{g}$ of folic acid in $100 \mathrm{ml}$ ) before treatment; preterm formula milk (containing $28 \mu \mathrm{g}$ of folic acid in $100 \mathrm{ml})$ and breast milk $(p=0.072)$ before treatment; preterm formula milk and breast milk $(p=0.071)$ after treatment.

\section{Discussion}

The importance of folic acid and the use of fortified nutrition is clear. It plays the leading role in decreasing the incidence of NTD and other congenital anomalies $(10,11,15)$. Prevention is always much better than subsequent medical care (12). To find optimal amounts, with the aim to provide optimal dose of folic acid in infants, is difficult. It follows from different amounts of folic acid in many types of infant nutrition, which were documented in Table 1. Preterm formula milks and breast milk fortifiers provide sufficient folic acid to prevent folate deficiency in preterm infants (13). This enteral nutritional supplementation is widely used in preterm babies in Neonatal Units (16). In our group of patients we confirmed the same results. The RBC folate concentration levels were significantly higher in newborns who were fed by breast milk with added fortifier. Overdose of folic acid could be a potential risk in preterm newborns (17). The preterm formula milks provide sufficient amount of folic acid according to manufacturer compared to expressed breast milk which contains $9 \mu \mathrm{g}$ of folic acid $(13,18)$. There is a question what changes the RBC folate concentration levels after delivery and during the first months of life. The case of breastfed infants independent of maternal folate status suggests that concentrations of folate positively correlate with the duration of exclusive breastfeeding. The serum folate was not higher in the formula-fed infants (19). The association between lactation and folate status was observed (20). From this study the results of RBC folate concentration levels were similar in the first two months of life in comparison with our previous findings related to Slovakian newborns (21). But it is still discussed where the top possible limit of tolerance in preterm newborns lies and the overdose risk in this group of patients remains unanswered. And different food habits and climate can alter RBC folate concentration levels in mothers and their newborns. By contrast, folate deficiency is very rare.

Folic acid is a part of a comprehensive treatment of anaemia in preterm newborns $(22,23)$. This comprehensive treatment with other micronutrients, iron and erythropoietin can decrease the number of blood transfusions (24). On the other hand, repeated blood transfusion can increase amount of these substances, e.g. folate (17) The daily amount of folic acid in this complex treatment varies from 50 to $100 \mu \mathrm{g}(22-24)$. The need to know the real RBC folate concentration levels seems to be crucial. In this work we presented a group of preterm newborns with measured RBC folate concentrations levels. The median of $\mathrm{RBC}$ folate concentration levels in our country on the first day of life is similar with our previous findings (25). The levels of RBC folate concentration decreases during the first days of life (26) but after full oral intake and/or due to other treatment the RBC folate concentration levels have changed, as confirmed by our current results. The recommended folic acid dose for newborns varies $(7,22,23)$. In our study the daily intake of folic acid was wide-ranging $(14 \mu \mathrm{g}$ in case of breast milk, $45 \mu \mathrm{g}$ in case of preterm formula milk and $93 \mu \mathrm{g}$ in case of breast milk with added fortifier according to average oral intake $160 \mathrm{ml} / \mathrm{kg} /$ day $)$, except for the folic acid treatment (100 $\mu \mathrm{g} /$ day) in our study. The amount of daily folic acid intake can vary due to other types of treatment, e. g. blood transfusion (22-24). After transfusion a temporary administration of folic acid is not necessary when the amount of folate in body is high (17). The best way is to know the real RBC folate concentration levels according to the gestational age to administer optimal amounts of folic acid.

The need for folic acid supplementation in the first weeks of life varies depending on the clinical state of newborns. In this work some clinical conditions were identified (infection, sepsis, respiratory distress syndrome, necrotizing enterocolitis, ductus arteriosus paterns, asphyxia, which potentiate anaemia of preterm newborns) that could affect blood count parameters but without any correlation to RBC folate concentration. In spite of developing anaemia the $\mathrm{RBC}$ folate concentration levels were increased. The authors postulate complicated mechanisms of changes in RBC folate levels, which is the most accurate indicator of the body's saturation with folic acid. The specific prenatal and early postnatal period with maternal reserves and optimal intake of folic acid after birth probably plays a key role.

\section{Conclusion}

This work enhances the knowledge about folic acid in the neonatal age. Folates are an important part of the growing body, especially in preterm newborns. Folic acid is also a part of the comprehensive treatment of anaemia, but is also a part of fortifiers and artificial milk formulas. In order to know the effect of this treatment, it is necessary to measure RBC folate concentration levels, which is the most accurate indicator of long-term folate level status in the body (the results are obtained from RBC, which are 
linked to life of the erythrocyte). Some clinical stages can decrease levels of folate in the body, but changes in folate remain questionable in spite of existing anemia, as was confirmed by our results.

The different amounts of folic acid in many types of infant nutrition used in the neonatal period and its impact on red blood cell folate concentration levels during first two months after birth vary. Breast milk has the leading position among the huge variety of milk products in neonatal nutrition as we estimate that the optimal nutrition comes from their mothers during pregnancy and lactation. With regard to preterm newborns, it is still a routine practice to fortify breast milk or use preterm infant formula. A large number of these products for preterm infants with different amounts of folic acid levels suggest the question of the real need of these patients as we documented it in this prospective study. The best way to administer adequate amounts of folic acid is to determine the real RBC folate concentration levels in preterm babies' bodies and calculate the optimal daily intake of folates based on the nutrition type (breast milk, milk formula, breast milk fortifier) and the treatment options (folic acid, vitamin supplements, blood transfusion) before administration of folic acid. After excessive intake of folic acid the administration should be temporary limited. We focus on the optimal supplementation of folic acid to prevent its excessive intake for preterm babies' bodies.

\section{References}

1. Elmadfa I, Meyer AL. Vitamins for the first 1000 days: preparing for life. Int J Vitam Nutr Res 2012; 82 (5): 342-347.

2. Tofail F, Persson LA, El Arifeen S, Hamadani JD, Mehrin F, Ridout D, Ekström EC, Huda SN, Grantham-McGregor SM. Effects of prenatal food and micronutrient supplementation on infant development: a randomized trial from the Maternal and Infant Nutrition Interventions, Matlab (MINIMat) study. Am J Clin Nutr 2008; 87 (3): 704-711.

3. Costello AM, Osrin D. Micronutrient status during pregnancy and outcomes for newborn infants in developing countries. J Nutr 2003; 133 (5 Suppl 2): 1757-1764.

4. Guardamagna O, Abello F, Cagliero P, Lughetti L. Impact of nutrition since early life on cardiovascular prevention. Ital J Pediatr 2012; 38: 73.

5. Yang Z, Huffman SL. Review of fortified food and beverage products for pregnant and lactating women and their impact on nutritional status. Matern Child Nutr 2011; 7 (Suppl. 3): 19-43.

6. Gregory JF. Folic acid supplementation and neural tube defect recurrence prevention. Birth Defects Res A Clin Mol Teratol 1997; 51 (Suppl 1): 554-559.

7. Kajaba I, Šimončič R, Ginter E, Ondrejka J, Trusková I, Kaláč J, Bzdúch V. Recommended nutritional doses for population of Slovak Republic - valid from 1997. Available at: http://www.jedalne.sk/sk/public/ tabulka1.pdf

8. Žikavská T, Brucknerová I. Position of folic acid in fortification of nutrition in neonatal period. Potravinarstvo 2013; 7 (1): 202-206.

9. Sweeney MR, McPartlin J, Weir DG, Daly S, Pentieva K, Daly L, Scott JM. Evidence of unmetabolized folic acid in cord blood of newborn and serum of 4-day-old infants. Br J Nutr 2005; 94: 727-730.

10. Banhidy F, Dakhlaoui A, Puho EH, Czeizel AE. Is there a reduction of congenital abnormalities in the offspring of diabetic pregnant women after folic acid supplementation? A population-based case-control study. Congenital Anomalies 2011; 51: 80-86.

11. Wilcox AJ, Lie RT, Solvoll K, Taylor J, McConnaughey DR, Abyholm F, Vindenes H, Vollset SE, Drevon CA. Folic acid supplements and risk of facial clefts: national population based case-control study. BMJ 2007; 335 (464): 1-6.

12. Horn F, Sabova L, Pinterova E, Hornova J, Trnka J. Prevention of neural tube defects by folic acid - awareness among women of childbearing age in Slovakia. Bratisl Med J 2014; 115 (2): 91-97.

13. Jyothi S, Misra I, Morris G, Benton A, Griffin D, Allen S. Red cell folate and plasma homocysteine in preterm infants. Neonatology 2007; 92: 264-268.

14. Zemlin AE, Essack Y, Rensburg M, Keller T, Krinkmann T. Stability of red blood cell folate in whole blood and haemolysate. Clin Lab 2010; 56 (9-10): 391-396.

15. Urbanova W, Kotova M, Vankova Z. The incidence of cleft lip and palate in the Czech Republic in 1994-2008. Bratisl Med J 2013; 114 (8): 474-479.

16. Ahmed M, Brent J, Ginn E. Use of enteral nutritional supplementation: a survey of level II and III neonatal units in England. J Coll Physicians Surg Pak 2013; 23 (9): 683-685.

17. Zikavska T, Brucknerova I. Extremely high concentration of folates in premature newborns. Bratisl Med J 2014; 115 (2): 103-106.

18. Mackey AD, Picciano MF. Maternal folate status during extended lactation and the effect of supplemental folic acid. Am J Clin Nutr 1999; 69 (2): 285-292.

19. Hay G, Johnston C, Whitelaw A, Trygg K, Refsum H. Folate and cobalamin status in relation to breastfeeding and weaning in healthy infants. Am J Clin Nutr 2008; 88 (1): 105-114.

20. Ramlau-Hansen CH, Moller UK, Henriksen TB, Nexo E, Moller J. Folate and vitamin B12 in relation to lactation: a 9-month postpartum follow-up study. Eur J Clin Nutr 2006; 60: 120-128.

21. Zikavska T, Brucknerova I. Safety and fortification with folic acid in neonatal period. Potravinarstvo 2013; 7 (1): 85-88.

22. Haiden N, Klebermass K, Cardona F, Schwindt J, Berger A, Kohlhauser-Vollmuth C, Jilma B, Pollak A. A randomized, controlled trial of effects of adding vitamin B12 and folate to erythropoetin for the treatment of anemia of prematurity. Pediatrics 2006; 118 (1): 180-188.

23. Hadler MC, Sigulem DM, Alves MF, Torres VM. Treatment and prevention of anemia with ferrous sulfate plus folic acid in children attending daycare centers in Goiânia, Goiás State, Brazil: a randomized controlled trial. Cad Saude Publica 2008; 24 (Suppl 2): 259-271.

24. Haiden, N, Schwindt J, Cardona F, Berger A, Klebermass K, Wald M, Kohlhauser-Vollmuth C, Jilma B, Pollak A. Effects of a combined therapy of erythropoietin, iron, folate, and vitamin B12 on the transfusion requirements of extremely low birth weight infants. Pediatrics 2006; 118 (5): 2004-2013.

25. Zikavska T, Brucknerova I, Vasilenkova A, Gallikova M. Red blood cell folate status on the first day of life in newborn and its specifics. CzechSlovak Pediatrics 2013; 68 (S1): 74.

26. Zikavska T, Brucknerova I, Behulova D, Vasilenkova A, Cervenova O. Specifics of folic acid intake in neonatal period. Czech-Slovak Pediatrics 2013; 68 (S1): 73.

Received June 24, 2014. Accepted Februar 13, 2015. 